\title{
PERLINDUNGAN HUKUM TERHADAP KREDITOR ATAS PENYUSUTAN NILAI OBJEK JAMINAN HAK TANGGUNGAN DALAM PERJANJIAN UTANG PIUTANG*
}

\author{
Oleh : \\ I Putu Yoga Putra Pratama** \\ Putu Tuni Cakabawa Landra***
}

Bagian Hukum Bisnis, Fakultas Hukum Universitas Udayana

\begin{abstract}
Abstrak
Karya tulis ini membahas tentang penyusutan nilai objek jaminan hak tanggungan dalam perjanjian utang piutang yang dapat merugikan kreditor karena tidak adanya pengaturan dalam UU Hak Tanggungan untuk melindungi kreditor. Masalah yang diangkat dalam karya tulis ini adalah bagaimana kedudukan kreditor terhadap debitor dalam perjanjian utang piutang dan bagaimana perlindungan hukum bagi kreditor atas penyusutan nilai objek jaminan hak tanggungan. Tujuannya adalah untuk mengetahui kedudukan kreditor terhadap debitor dalam perjanjian utang piutang dan untuk menemukan konsep perlindungan hukum terhadap kreditor atas penyusutan nilai objek jaminan hak tanggungan. Metode penelitian yang digunakan adalah penelitian hukum normatif dengan menggunakan pendekatan perundangundangan dan pendekatan konseptual. Hasil dan analisisnya adalah kedudukan kreditor dalam perjanjian utang piutang lebih kuat dibandingkan dengan debitor, hal ini karena debitor yang memerlukan bantuan berupa pinjaman sebagai bentuk kepentingan dari diri debitor dan dapat diterapkannya perjanjian baku oleh kreditor tanpa melakukan perundingan terlebih dahulu dengan debitor. Sementara perlindungan hukum terhadap kreditor apabila terjadi penyusutan nilai objek jaminan hak tanggungan maka pihak kreditor dapat meminta pelunasan piutang yang belum terjangkau pemenuhannya, karena utang merupakan kewajiban yang harus dipenuhi debitor. Berdasarkan Pasal 1131 KUHPerdata pemenuhannya dapat dilakukan dengan benda bergerak maupun tak bergerak milik debitor baik yang sudah ada maupun yang akan
\end{abstract}

\footnotetext{
* Perlindungan Hukum Terhadap Kreditor atas Penyusutan Nilai Objek Jaminan Hak Tanggungan dalam Perjanjian Utang Piutang merupakan karya ilmiah di luar ringkasan skripsi.

** I Putu Yoga Putra Pratama adalah penulis pertama dalam karya ilmiah ini yang merupakan mahasiswa Fakultas Hukum Universitas Udayana.

${ }^{* * *}$ Dr. Putu Tuni Cakabawa Landra, SH., M.Hum adalah penulis kedua dalam karya ilmiah ini yang merupakan dosen Fakultas Hukum Universitas Udayana.
} 
ada dikemudian hari sampai terjadinya pelunasan atas utang debitor.

\title{
Kata kunci : utang piutang, jaminan, perlindungan hukum
}

\begin{abstract}
This paper discusses depreciation value of the collateral rights object in the debt agreement which can be detrimental to the creditor because there is no regulation in the Law of Encumbrance Right to protect creditor. The problem raised in this paper is how the position of creditor to debtor in the debt agreement and how the legal protection for creditor on depreciating value of the collateral rights object. The purpose is to find out the position of creditor to debtor in the debt agreement and to find the concept of legal protection against creditor for depreciating value of the collateral rights object. The research method used is normative legal research using a legal approach and conceptual approach. The results and analysis is the position of creditor in the debt agreement is stronger than the debtor, this is because the debtor who needs assistance in the form of loans as a interest from the debtor and can apply the standard contract by creditor without negotiating with the debtor beforehand. While legal protection against creditor in the event depreciation value of the collateral rights object, the creditor can ask for repayment of accounts receivable that have not reached fulfillment, because debt is an obligation that must be fulfilled by debtor. Based on Article 1131 of the Civil Code the fulfillment of this can be done with movable or immovable object owned by the debtor both existing or will have in the future until the repayment of debtor debt.
\end{abstract}

\section{Key words : debt, collateral, legal protection}

\section{PENDAHULUAN}

\subsection{Latar Belakang}

Manusia dalam memenuhi kebutuhan hidup, cenderung selalu memerlukan bantuan orang lain karena setiap manusia memiliki kebutuhan yang berbeda-beda satu dengan yang lainnya. Dalam memenuhi kebutuhan hidup, uang sebagai benda yang bernilai ekonomis pada umumnya dijadikan sebagai alat tukar untuk memperoleh benda yang menjadi kebutuhan manusia.

Dalam kehidupan di masyarakat, tidak semua orang memiliki uang yang cukup untuk memenuhi kebutuhan hidup 
mereka. Atas hal tersebut maka tak jarang orang akan meminjam uang kepada orang yang memiliki uang lebih untuk dapat memenuhi kebutuhan hidup. Tak jarang orang yang meminjam uang atau berutang, memiliki maksud yang tidak baik untuk tidak mengembalikan uang yang dipinjamnya itu. Hal tersebut bisa saja didasari karena tidak ada pernyataan tertulis sebelumnya terkait perjanjian utang piutang dan juga yang terpenting ialah tidak adanya benda sebagai jaminan untuk peminjaman uang yang dilakukan sebagai antisipasi apabila si peminjam uang cidera janji.

Seiring dengan perkembangan dan pertumbuhan di bidang ekonomi yang terus mengalami kemajuan, maka untuk memfasilitasi peminjaman uang oleh masyarakat guna memenuhi kebutuhan hidup, terdapat lembaga keuangan yang kegiatannya memberikan pelayanan jasa dibidang keuangan. Lembaga keuangan inilah yang membantu masyarakat yang membutuhkan dana untuk dapat memperoleh dana guna memenuhi kebutuhan hidup mereka.

Lembaga keuangan perbankan dalam melakukan perjanjian pemberian pinjaman uang ini diistilahkan dengan perjanjian kredit, dimana dalam perjanjian kredit terdapat dua pihak, yaitu pihak yang memberikan pinjaman uang/pihak yang berpiutang dinamakan kreditor, dan pihak yang menerima pinjaman/pihak yang berutang dinamakan debitor. Dalam perjanjian kredit selalu terdapat risiko di dalamnya yang apabila risiko tersebut tidak diantisipasi dapat menimbulkan kerugian bagi pihak kreditor. Menurut Prof. Subekti, SH dalam bukunya Hukum Perjanian, bahwa yang dimaksud dengan risiko adalah kewajiban memikul kerugian yang disebabkan karena suatu kejadian di luar kesalahan salah 
satu pihak. ${ }^{1}$ Atas dasar adanya risiko tersebut maka dalam perjanjian kredit terdapat adanya jaminan sebagai antisipasi apabila debitor wanprestasi maka jaminan tersebut nantinya akan dilelang dan hasil dari pelelangan tersebut digunakan untuk melunasi utang debitor.

Benda yang dijadikan jaminan disini adalah benda bergerak maupun benda tidak bergerak. Berkaitan dengan jaminan benda tidak bergerak misalnya tanah, terdapat pengaturannya dalam Undang-Undang Nomor 4 Tahun 1996 tentang Hak Tanggungan atas Tanah Beserta Benda-Benda yang Berkaitan dengan Tanah (selanjutnya disebut UU Hak Tanggungan). Dimana apabila melihat nilai ekonomis dari tanah, semakin hari harga tanah dapat dihitung pasti mengalami suatu peningkatan, sehingga kreditor dalam memberikan pinjaman kredit biasanya kurang memperhatikan asas kehati-hatian dalam perkreditan apabila objek jaminannya berupa tanah. Permasalahan yang mungkin timbul nantinya adalah apabila terjadi suatu keadaan pada objek jaminan yang berupa tanah tersebut sehingga nilai objek jaminan tanah itu mengalami penyusutan, tentu kreditor akan mengalami kerugian. Padahal sudah ditegaskan dalam Pasal 6 UU Hak Tanggungan bahwa apabila terjadi wanprestasi, pemegang hak tanggungan pertama dapat menjual objek hak tanggungan serta dari hasil penjualan dapat mengambil pelunasan utangnya.

Dalam UU Hak Tanggungan tidak ada pengaturan yang konkret terkait dapat atau tidaknya kreditor meminta uang kepada debitor untuk pemenuhan piutangnya karena nilai objek jaminan berupa tanah tersebut tidak mampu lagi menjangkau utang debitor. Ini merupakan bentuk kekosongan ketentuan hukum dalam UU

1 Hermansyah, 2014, Hukum Perbankan Nasional Indonesia, Prenada Media Group, Jakarta, hlm. 60. 
Hak Tanggungan untuk dapat melindungi kreditor. Melihat juga sebelumnya telah ada kesepakatan antar pihak untuk pelunasan utang debitor apabila wanprestasi dapat melakukan pelelangan atas objek jaminan hak tanggungan tersebut. Hal itu tentunya mengikat kreditor dengan adanya perjanjian jaminan hak tanggungan. Oleh karena itu perlu adanya pengaturan dalam UU Hak Tanggungan apabila objek jaminan hak tanggungan mengalami penyusutan dan perlu ditelaah teori serta peraturan terkait sebagai konsep perlindungan hukum bagi kreditor dan juga pemberian kewajiban kepada debitor untuk melunasi sebagian utangnya yang belum terjangkau atas penjualan objek jaminan hak tanggungan.

\subsection{Rumusan Masalah}

Berdasarkan latar belakang yang telah diuraikan di atas, dapat dirumuskan beberapa rumusan masalah, sebagai berikut :

1. Bagaimana kedudukan kreditor terhadap debitor dalam perjanjian utang piutang ?

2. Bagaimana perlindungan hukum bagi kreditor apabila nilai objek jaminan hak tanggungan mengalami penyusutan?

\subsection{Tujuan Penulisan}

Adapun tujuan dari penulisan ini, yaitu untuk menemukan konsep perlindungan hukum yang diperoleh kreditor dalam hal terjadi penyusutan nilai dari objek jaminan hak tanggungan pada perjanjian utang piutang apabila si debitor cidera janji, serta mengetahui kedudukan kreditor terhadap debitor dalam perjanjian utang piutang.

\section{ISI MAKALAH}

\subsection{Metode Penelitian}

Jenis penelitian dalam tulisan ini yang digunakan adalah penelitian hukum normatif yang meneliti hukum dari perspektif 
internal $^{2}$ dengan objek penelitiannya adalah kekosongan ketentuan hukum dalam perlindungan terhadap kreditor atas penyusutan nilai objek jaminan hak tanggungan. Penelitian ini menggunakan pendekatan perundang-undangan (statue approach) dan pendekatan konseptual (conseptual approach) yang berkaitan dengan jaminan hak tanggungan. Bahan hukum yang digunakan adalah bahan hukum primer yaitu Undang-Undang Republik Indonesia Nomor 4 Tahun 1996 tentang Hak Tanggungan atas Tanah Beserta Benda-Benda yang Berkaitan dengan Tanah dan juga Kitab Undang-Undang Hukum Perdata (KUHPerdata), sedangkan untuk bahan hukum sekunder menggunakan literatur yang terkait dengan jaminan hak tanggungan dan perjanjian utang piutang.

\subsection{Hasil dan Analisis}

\subsubsection{Kedudukan Kreditor Terhadap Debitor dalam Perjanjian Utang Piutang}

Utang piutang merupakan perjanjian yang sering terjadi antara para pihak di masyarakat, hal ini merupakan bentuk bahwa perjanjian utang piutang merupakan perjanjian yang penting dilakukan dalam keadaan tertentu oleh para pihak yang berkepentingan. Perjanjian utang piutang termasuk ke dalam jenis perjanjian pinjam meminjam dan tunduk pada ketentuan yang terdapat dalam KUHPerdata yakni pada Bab Ketiga Belas Buku Ketiga mengenai Perikatan. Dalam Pasal 1754 KUHPerdata menyebutkan bahwa, pinjam meminjam adalah suatu perjanjian dimana pihak yang satu memberi suatu barang dengan jumlah tertentu yang habis karena pemakaian kepada pihak lain, dengan

2 I Made Pasek Diantha, 2017, Metodologi Penelitian Hukum Normatif dalam Justifikasi Teori Hukum, Prenada Media Group, Jakarta, hlm. 12. 
syarat bahwa pihak yang diberikan ini akan mengembalikan sejumlah, macam, dan keadaan yang sama pula. ${ }^{3}$

Perjanjian utang piutang dapat terjadi pada pokoknya dilatar belakangi karena sejarah timbulnya utang piutang tersebut. Terjadinya perjanjian utang piutang ada dua macam, yaitu karena murni perjanjian utang-piutang dan karena dilatar belakangi perjanjian lain. Perjanjian utang piutang murni yang dimaksud disini karena tidak ada latar belakang persoalan lain sebelumnya, dan perjanjian utang piutang itu dibuat hanya semata-mata untuk melakukan utang piutang. Sebagai contoh seorang ibu rumah tangga yang kehabisan uang untuk memenuhi kebutuhan hidup keluarga mereka, kemudian pergi ke bank untuk meminjam uang. Dapat dilihat bahwa perjanjian terjadi karena murni kepentingan utang piutang. Sedangkan perjanjian utang piutang yang dilatar belakangi perjanjian lain terjadi oleh sebab telah ada perjanjian lain sebelumnya. Perjanjian sebelumnya dengan perjanjian berikutnya yaitu perjanjian utang piutang kedudukannya berdiri sendiri. ${ }^{4}$

Dalam perjanjian utang piutang terdapat dua pihak yang melakukan perjanjian dan bersedia untuk mengikatkan diri mereka sesuai dengan syarat yang di tentukan oleh para pihak tanpa melanggar asas-asas umum dalam perjanjian. Pihak-pihak dalam perjanjian utang piutang, yaitu pihak kreditor dan pihak debitor. Pihak kreditor disini sebagai pihak yang memberikan pinjaman atau pihak yang berpiutang, sedangkan pihak debitor adalah pihak yang menerima pinjaman atau pihak yang berutang. Perjanjian utang piutang terdapat di dalamnya hak dan kewajiban yang timbul di antara para pihak yang melakukan perjanjian. Pihak kreditor memiliki hak untuk menerima kembali uang yang dipinjamkan itu

${ }^{3}$ Gatot Supramono, 2014, Perjanjian Utang Piutang, Prenada Media Group, Jakarta, hlm. 9.

${ }_{4}^{4}$ Ibid, hlm. 11. 
termasuk bunga yang timbul karenanya, sementara kewajibannya yaitu menyerahkan uang sampai ke tangan debitor sejumlah yang disepakati kedua belah pihak. Sedangkan hak yang dimiliki oleh debitor yaitu menerima uang yang disepakati kedua belah pihak sebagai utang oleh debitor, sementara kewajibannya adalah membayar uang yang dipinjam itu kembali dikemudian hari kepada kreditor baik itu secara tunai ataupun angsuran.

Kedua pihak yang melakukan perjanjian utang piutang, baik kreditor maupun debitor memiliki kedudukan yang berbeda. Pihak kreditor pada umumnya memiliki kedudukan yang lebih kuat secara finansial dibandingkan dengan pihak debitor, hal ini dikarenakan pihak debitor lah yang memerlukan bantuan dari kreditor untuk dapat melakukan pinjaman/berutang sebagai bentuk kepentingan dari diri debitor. Walaupun kedudukan kreditor lebih kuat dibandingkan dengan debitor, tidak lantas membuat kreditor menjadi sewenang-wenang dalam hal menentukan isi klausul perjanjian utang piutang, tentu saja dalam menentukan isi klausul perjanjian utang piutang harus melalui perundingan kedua belah pihak agar isi klausul perjanjian dapat disepakati oleh kedua pihak dan dapat ditaati tanpa adanya tekanan maupun paksaan.

Meskipun demikian, namun tak jarang kreditor menerapkan perjanjian baku (standard contract) untuk mempercepat proses perjanjian utang piutang. Perjanjian baku ini merupakan perjanjian yang hampir seluruh klausul-klausul dalam perjanjian dibakukan dalam artian dibuat sepihak oleh pihak kreditor sehingga pihak yang lain tidak mempunyai kesempatan untuk merundingkan atau meminta perubahan. ${ }^{5}$ Kreditor yang menerapkan perjanjian baku

5 Putu Lingga Prabhawati dan I Nengah Suantra, 2018, Pemberlakuan Perjanjian Baku (Standard Contract) Dalam Praktik Usaha Transportasi Online Terkait Tanggung Jawab Pelaku Usaha, Vol. 06 No. 02, Kertha Semaya, Fakultas 
ini umumnya adalah kreditor yang berupa lembaga keuangan seperti bank dengan tujuan agar perjanjian dapat dilakukan secara cepat dan praktis. Namun, walaupun perjanjian utang piutang dibuat dalam bentuk perjanjian baku, tidak berarti menghilangkan unsur kesepakatan para pihak disana, pihak debitor tetap diberikan kesempatan untuk menerima atau tidak isi dari perjanjian baku yang ditawarkan dengan cara bersedia menandatangani atau tidak. Apabila pihak debitor bersedia untuk menandatangani perjanjian baku tersebut, maka pihak debitor sepakat untuk mengikatkan diri terhadap perjanjian tersebut.

Unsur kesepakatan dalam perjanjian utang piutang itu memang mutlak harus ada, walaupun perjanjian utang piutang dibuat dalam bentuk perjanjian baku. Sehingga berdasarkan Pasal 1338 KUHPerdata, perjanjian nantinya dapat berlaku seperti undang-undang bagi mereka yang membuatnya. Adanya perjanjian baku ini yang dibuat umumnya oleh pihak kreditor, menunjukkan kedudukan kreditor yang lebih kuat sehingga dapat bertindak untuk mengendalikan debitor dalam hal menetapkan isi perjanjian secara sepihak dalam perjanjian baku. Sehingga kedudukan lebih kuat kreditor disini dapat dilihat dari adanya pihak debitor yang memerlukan bantuan berupa pinjaman dari kreditor dan dapat diterapkannya perjajian baku oleh pihak kreditor.

\subsubsection{Perlindungan Hukum Terhadap Kreditor atas Penyusutan Nilai Objek Jaminan Hak Tanggungan}

Kegiatan utang piutang yang dilakukan memang bertujuan untuk meningkatkan kegiatan perekonomian yang sejalan dengan meningkatkan taraf kehidupan masyarakat. Namun, dalam

Hukum Universitas Udayana, Denpasar, hlm. 5, URL : https://ojs.unud.ac.id/index.php/kerthasemaya/article/view/38416, diakses pada tanggal 7 April 2019. 
kegiatan tersebut juga mengandung risiko yang apabila tidak diantisipasi tentunya akan merugikan kedua belah pihak khususnya pihak kreditor. Sebagai antisipasi dari risiko tersebut maka peranan jaminan sangat lah penting ada dalam setiap dilakukannya perjanjian utang piutang. Menurut Hartono Hadisoeprapto berpendapat bahwa jaminan adalah sesuatu yang diberikan yang dapat dinilai dengan uang untuk menimbulkan keyakinan kepada kreditor bahwa debitor akan memenuhi kewajiban yang timbul dari suatu perikatan. ${ }^{6}$ Fungsi jaminan disini adalah untuk melunasi pinjaman yang telah diberikan oleh kreditor, dengan demikian fungsi jaminan adalah untuk mengamankan pelunasan utang bila debitor cidera janji juga berfungsi sebagai bentuk kesungguhan pihak debitor untuk memenuhi kewajibannya sesuai dengan yang diperjanjikan, dan menggunakan uang yang dipinjamnya secara baik dan berhati-hati. Sifat manusia untuk berusaha mempertahankan apa yang menjadi miliknya dan memiliki nilai yang berharga, menjadi dasar hukum jaminan ${ }^{7}$, sehingga debitor sebagai pihak yang memberi jaminan akan berusaha melunasi utangnya guna mengambil kembali apa yang dijaminkannya.

Jaminan dapat berupa kebendaan dan perorangan. Jaminan kebendaan disini dapat dinilai dengan uang yang senilai atau melebihi nilai utang agar terpenuhinya pemenuhan utang apabila si debitor cidera janji. Sedangkan jaminan perorangan berupa janji penanggungan sejumlah utang yang dimiliki debitor. Penjamin dalam jaminan perorangan tentu saja bukan merupakan diri debitor sendiri, melainkan orang lain/pihak ketiga yang dapat berupa

6 Salim H.S, 2016, Perkembangan Hukum Jaminan di Indonesia, PT RajaGrafindo Persada, Jakarta, hlm. 22.

7 J. Satrio, 2002, Hukum Jaminan, Hak-Hak Jaminan Kebendaan, Citra Aditya Bakti, Bandung, hlm. 12. 
perorangan atau korporasi yang berbadan hukum maupun tidak berbadan hukum dengan mengadakan kesepakatan terhadap pihak kreditor bahwa dirinya bersedia menanggung pelunasan utang debitor kepada kreditor. Subekti mengartikan jaminan perorangan adalah suatu persetujuan antara kreditor dengan pihak ketiga sebagai penjamin, yang bersedia menanggung dipenuhinya kewajiban debitor untuk pelunasan utangnya baik atas sepengetahuan si debitor sendiri maupun tanpa sepengetahuan si debitor. $^{8}$

Mengenai jaminan kebendaan, menurut sifatnya dapat dibagi menjadi benda bergerak dan benda tidak bergerak. Bendabenda yang dijamin itu merupakan milik debitor yang tidak dapat dialihkan atau dipindahtangankan selama menjadi jaminan utang, baik oleh kreditor maupun oleh debitor sendiri. Benda yang menjadi objek jaminan dapat dilihat dari sifatnya untuk dapat mengetahui termasuk benda bergerak atau tidak bergerak. Apabila suatu benda dapat dipindahkan dari tempatnya, maka termasuk benda bergerak. Sebaliknya, apabila suatu benda tidak dapat dipindahkan dari tempatnya, maka termasuk benda tidak bergerak. Jenis benda tersebut, apabila dibebani dengan jaminan utang akan mempengaruhi macam jaminannya. Untuk benda tidak bergerak yang wujudnya berupa tanah jenis jaminannya adalah hak tanggungan dan tunduk pada UU Hak Tanggungan. Hak tanggungan tidak dapat berdiri sendiri melainkan harus didukung oleh suatu perjanjian yang mendahuluinya (perjanjian utang piutang) antara kreditor dengan debitor, oleh sebab itu hak tanggungan dikatakan accessoir (mengikuti perjanjian pokok). ${ }^{9}$

8 Subekti, 1996, Jaminan-Jaminan Untuk Pemberian Kredit Termasuk Hak Tanggungan Menurut Hukum Indonesia, Citra Aditya Bakti, Bandung, hlm. 17.

9 Mitia Intansari dan I Made Walesa Putra, 2016, Kedudukan Kreditur Pemegang Hak Tanggungan Dalam Hal Debitur Wanprestasi, Vol. 04 No. 03, Kertha Semaya, Fakultas Hukum Universitas Udayana, Denpasar, hlm. 4, URL : 
Tanah yang merupakan benda tidak bergerak dapat dan sering dibebankan dengan jaminan hak tangggungan oleh para debitor untuk kepentingan utang. Nilai ekonomis tanah yang terus mengalami peningkatan sering membuat kreditor kurang meperhatikan prinsip kehati-hatian dalam perkreditan, sehingga apabila terdapat suatu keadaan yang membuat nilai ekonomis objek jaminan hak tanggungan berupa tanah itu kemudian mengalami penyusutan, maka di sini pihak kreditor lah yang dirugikan. Dimana sebelumnya pihak kreditor juga telah sepakat dalam hal debitor wanprestasi maka kreditor akan mengambil pelunasan piutang dari hasil pelelangan objek jaminan. Hal ini tentunya mengikat kreditor. Di sisi lain, hasil pelelangan atas objek jaminan tersebut tidak dapat menjangkau pelunasan utang debitor. Sehingga dalam keadaan demikian yang terjadi, kreditor seakan tidak dapat menagih pemenuhan piutang yang belum terjangkau atas hasil pelelangan objek jaminan. Dalam UU Hak Tanggungan juga tidak ada ketentuan yang memungkinkan kreditor untuk dapat memperoleh pemenuhan atas piutang, apabila terjadinya penyusutan nilai objek jaminan hak tanggungan yang berupa tanah ini. Dalam Pasal 11 ayat (2) huruf i UU Hak Tanggungan hanya disebutkan dalam Akta Pemberian Hak Tanggungan (APHT) dapat dicantumkan janji bahwa pemegang hak tanggungan akan memeproleh ganti rugi baik seluruh maupun sebagian oleh pemberi hak tanggungan untuk pelunasan piutangnya bila objek hak tanggungan dilepaskan haknya atau dicabut untuk kepentingan umum. Janji yang dapat dicantumkan dalam APHT hanya sebatas apabila objek hak tanggungan itu dilepaskan atau dicabut haknya, tidak dalam hal terjadinya penyusutan nilai objek jaminan. Hal ini

https://ojs.unud.ac.id/index.php/kerthasemaya/article/view/20941, diakses pada tanggal 14 April 2019. 
membuat terdapatnya kekosongan ketentuan hukum dalan UU Hak Taggungan untuk melindungi kreditor dalam hal terjadinya penyusutan nilai ekonomis tanah yang merupakan objek jaminan hak tanggungan.

Pelelangan atas objek jaminan hak tanggungan yang berupa tanah untuk pelunasan utang, tidak secara serta merta membuat perjanjian utang piutang tersebut selesai. Dalam hal hasil pelelangan objek jaminan hak tanggungan mencukupi atau melampaui nilai utang, maka tentu saja pemenuhan atas utang debitor dapat dilakukan, sehingga perjajian utang piutang antara debitor dengan kreditor dapat berakhir oleh karena sudah dipenuhinya utang debitor atas hasil pelelangan objek jaminan. Namun, apabila hasil pelelangan objek jaminan hak tanggungan belum mencukupi atau baru mencukupi sebagian saja untuk pelunasan utang debitor, maka sisa dari pelunasan utang debitor yang belum terpenuhi tersebut tetap merupakan utang debitor yang harus dibayarkan oleh debitor sendiri. Utang disini adalah merupakan kewajiban bagi debitor, yakni apabila belum terpenuhinya utang sudah merupakan kewajiban bagi debitor untuk membayarnya hingga tercapai pelunasan atas utang tersebut. Melihat Kitab Undang-Undang Hukum Perdata (KUHPerdata), dalam Pasal 1131 menyebutkan bahwa semua benda-benda milik debitor baik benda bergerak maupun benda tidak bergerak, baik yang sudah ada maupun yang akan ada di kemudian hari, menjadi jaminan atas perikatan-perikatan perorangan debitor. Atas hal tersebut apabila benda yang menjadi objek jaminan hak tanggungan yakni tanah tersebut belum mampu untuk melunasi utang debitor, maka benda-benda debitor yang lainnya merupakan sebagai jaminan juga atas sebagian utang 
debitor yang belum terlunasi itu, sehingga tujuan akhir nantinya adalah sampai pada pelunasan utang debitor.

Melihat pula kedudukan kreditor terhadap debitor yang telah dibahas pada pembahasan sebelumnya, yang dimana kedudukan kreditor lebih kuat dibandingkan dengan debitor, tidak lantas membuat kedudukan kreditor dalam hukum jaminan diperlemah, dalam hal tidak adanya perlindungan hukum terhadap kreditor apabila nilai objek jaminan hak tanggungan yang berupa tanah mengalami penyusutan. Melainkan kreditor tetap memiliki kedudukan yang kuat untuk dapat menagih pelunasan piutang kepada debitor yang baru dipenuhi sebagian dari hasil pelelangan objek jaminan hak tanggungan, baik itu dengan pelunasan secara angsuran ataupun secara tunai lagsung, sesuai syarat dan ketentuan yang disepakati oleh kedua belah pihak, baik kreditor maupun debitor.

\section{PENUTUP}

\subsection{Kesimpulan}

Dari pembahasan di atas dapat ditarik kesimpulan, sebagai berikut :

Kedudukan kreditor terhadap debitor dalam perjanjian utang piutang adalah kreditor berkedudukan lebih kuat dibandingkan dengan debitor atas dasar kreditor sebagai pihak yang memberi pinjaman kepada debitor sehingga peran kreditor sangat dibutuhkan oleh debitor dalam hal membantu pemberian pinjaman utang kepada debitor, dan dapat diterapkannya perjanjian baku oleh kreditor yang klausulnya bebas ditentukan oleh kreditor sendiri tanpa adanya perundingan terlebih dahulu dengan debitor. Kedudukan kreditor yang lebih kuat dibandingkan dengan debitor ini, kemudian tidak membuat kedudukan kreditor menjadi diperlemah dalam hukum jaminan karena tidak adanya 
pengaturan mengenai perlindungan hukum terhadap kreditor apabila nilai objek jaminan hak tanggungan mengalami penyusutan. Konsep perlindungan hukumnya adalah kreditor tetap berhak untuk meminta pelunasan atas piutang yang belum terjangkau pemenuhannya dari hasil pelelangan objek yang menjadi jaminan, meskipun dalam UU Hak Tanggungan tidak terdapat ketentuan yang mengatur demikian, bedasarkan ketentuan Pasal 1131 KUHPerdata dimana benda-benda milik debitor dijadikan pemenuhan atas utang debitor yang belum terpenuhi pelunasannya, karena utang adalah merupakan suatu kewajiban yang harus dibayar untuk dicapainya pelunasan atas utang.

\subsection{Saran}

Perjanjian utang piutang dalam kehidupan sekarang ini, sudah menjadi suatu kebutuhan sebagian besar masyarakat, dimana jaminan merupakan salah satu unsur terpentingnya. Diharapkan agar perlindungan terhadap kreditor sebagai pihak yang menerima jaminan perlu dilakukan melalui pengaturan dalam UU Hak Tanggungan dalam keadaan terjadi penyusutan nilai objek yang menjadi jaminan di kemudian hari, sehingga kreditor tidak dirugikan. Diharapkan juga para pihak yang melakukan perjanjian utang piutang, dengan itikad baik dapat melaksanakannya sesuai dengan isi dan ketentuan dalam perjanjian, agar tidak merugikan salah satu pihak.

\section{DAFTAR PUSTAKA}

\section{Buku-Buku :}

Diantha, I Made Pasek, 2017, Metodologi Penelitian Hukum Normatif dalam Justifikasi Teori Hukum, Prenada Media Group, Jakarta.

Hermansyah, 2014, Hukum Perbankan Nasional Indonesia, Prenada Media Group, Jakarta. 
HS, Salim, 2016, Perkembangan Hukum Jaminan di Indonesia, PT RajaGrafindo Persada, Jakarta.

Satrio, J., 2002, Hukum Jaminan, Hak-Hak Jaminan Kebendaan, Citra Aditya Bakti, Bandung.

Subekti, 1996, Jaminan-Jaminan Untuk Pemberian Kredit Termasuk Hak Tanggungan Menurut Hukum Indonesia, Citra Aditya Bakti, Bandung.

Supramono, Gatot, 2014, Perjanjian Utang Piutang, Prenada Media Group, Jakarta.

\section{Jurnal Ilmiah :}

Intansari, Mitia dan I Made Walesa Putra, 2016, Kedudukan Kreditur Pemegang Hak Tanggungan Dalam Hal Debitur Wanprestasi, Vol. 04 No. 03, Kertha Semaya, Fakultas Hukum Universitas Udayana, Denpasar.

Prabhawati, Putu Lingga dan I Nengah Suantra, 2018, Pemberlakuan Perjanjian Baku (Standard Contract) Dalam Praktik Usaha Transportasi Online Terkait Tanggung Jawab Pelaku Usaha, Vol. 06 No. 02, Kertha Semaya, Fakultas Hukum Universitas Udayana, Denpasar.

\section{Peraturan Perundang-Undangan :}

Indonesia, 1996, Undang-Undang Nomor 4 Tahun 1996 tentang Hak Tanggungan atas Tanah Beserta Benda-Benda yang Berkaitan dengan Tanah, Lembaran Negara Republik Indonesia Tahun 1996, Nomor 42, Tambahan Lembaran Negara Nomor 3632, Menteri Negara Sekretaris Negara, Jakarta. 